\title{
HYDRO-PRIMING OF SEED IMPROVES THE WATER USE EFFICIENCY, GRAIN YIELD AND NET ECONOMIC RETURN OF WHEAT UNDER DIFFERENT MOISTURE REGIMES
}

\author{
Raj Pal Meena*, Sendhil R, S. C. Tripathi, Subhash Chander, \\ R. S. Chhokar and R. K. Sharma \\ Directorate of Wheat Research, Karnal, Haryana 132001, India
}

\begin{abstract}
Wheat is the second most important staple food crop of India and contributes a major share to food basket of the country. Since majority of the area under wheat is irrigated, it consumes huge quantity of fresh water for its cultivation. The availability of good quality water for irrigation is decreasing over a period of time due to vagaries of monsoon, urbanization and industrialization. The biggest challenge on this front is to improve the efficiency and productivity of water being used in existing cropping system. Therefore, it is the need of hour to improve water use efficiency for wheat production. In the milieu, the present investigation was taken with an objective of studying the effect of pre-germinated seed in crop establishment under sub-optimal soil moisture conditions by using the residual soil moisture after harvesting of rice in Indo-Gangetic plains, so that pre sowing irrigation requirement for crop establishment may be cut and reduced in time period which require from pre-sowing irrigation to field preparation. This experiment was conducted for two consecutive years 2010-11 and 2011-12 to evaluate the influence of hydropriming on the water use efficiency and grain yield of wheat (Triticum aestivum L.) under moisture stress. The experiment was conducted in split plot design with three replications keeping moisture stress treatments (optimum moisture, sub-optimal moisture and dry soil followed by irrigation) in main plots and seed priming treatments (dry seed, hydropriming, and pre-germinated seeds) in subplots. Pregerminated seed produced significantly higher grain yield $\left(5.49 \mathrm{t} \mathrm{ha}^{-1}\right)$, which was statistically similar to hydropriming $\left(5.30 \mathrm{t} \mathrm{ha}^{-1}\right)$. Various seeding methods were statistically at par. The hydro-primed and pregerminated seeds established earlier than dry seeds leading to better crop establishment under optimum, sub optimum soil moisture as well as dry soil conditions leading to higher tillering and grain yield. The results
\end{abstract}

\footnotetext{
*Corresponding author email: adityarajjaipur@gmail.com
} 
of experiment showed that priming with plain water and pre-germinated seeds improved germination indices, seedling growth and crop establishment. Since priming with plain water and to have pregerminated seeds is simple and cheap method, which can increase germination percentage and homogeneity of seedling emergence under water stress conditions and it can be easily used by farmers. Interactive effect of different seed priming techniques along with seeding at sub optimal soil moisture level proved to be an efficient technique for enhancing water productivity of wheat crop.

Keywords: Economics, seed priming, yield, water productivity and wheat

\section{INTRODUCTION}

Wheat (Triticum aestivum L.), is the most important cereal crop and is also staple food for millions of people around the world. Irrigation water decreasing and drought are the major factor limiting crop growth and productivity in many regions of the world, the loss of which is more than any other single environmental factor (Farooq et al., 2009a).Wheat yields in the South Asia where rice-wheat cropping system is following, are suffering due to delayed sowing owing to late harvesting of rice, short period of winter seasons, less developed facilities of irrigation and poor crop stands due to lack of optimal moisture. The availability of good quality water is decreasing with time due to higher population pressure, urbanization and industrialization. However, changing global climate is making the situation more serious (IPCC 2007). Water deficit during initial stage of crop results in delayed and erratic seedling emergence and stand establishment and in severe cases, complete inhibition of seedling emergence may also result (Kaya et al., 2006). The biggest challenge on this front is to improve the efficiency and productivity of water being used in existing systems. Harris (1996) demonstrated that simply soaking seeds in plain water before sowing could increase the speed and homogeneity of germination and emergence, leading to better crop stands, and stimulated seedlings to grow much more vigorously. Hydro priming, a simple hydration technique to a point of pregermination metabolisms without actual germination (Farooq et al., 2009b), is one of the most pragmatic, simple, economic and short-term approaches to combat the effects of drought (Kaya et al., 2006) and other abiotic stresses (Jafar et al., 2012) on seedling emergence and crop establishment. Hydro primed seeds usually have early, higher and synchronized germination owing to reduction in the lag time of imbibitions otherwise required much time (Brocklehurst and Dearman 2008) and build-up of germination enhancing metabolites (Farooq et al., 2006). Preliminary research has also identified a number of opportunities for priming to be used as a vehicle to introduce biofertilizers, micronutrients and crop protection agents into seeds. Studies also suggested that it is possible to prime seeds with small amount of phosphate to good effect in the early root growth is stimulated allowing more effective uptake of available P in the soil (Johanson et al., 2004). Rajpar et al., (2006) 
reported that hydro-priming improved wheat yield under non-saline conditions. Good establishment increases competitiveness against weeds, increases tolerance to abiotic stress especially dry spells and ultimately maximizes the yields (Clark et al., 2001). Direct benefits due to seed priming includes, faster emergence, better and more uniform stands, more vigorous plants, better drought tolerance, earlier flowering and higher grain yield in many crops (Harris et al., 1999; Harris and Hollington, 2001).

Wheat is the second most important staple food crop of India and contributes major share to food basket (93.9 MT in 2011-12) of the country (Sharma et al., 2013). The present water productivity of wheat is 1500 litres of water $/ \mathrm{kg}$ of wheat grain (FAO, 2012). Since 90 per cent of wheat crop is grown in irrigated condition, thus it consumes huge quantity of fresh water for its production (Agricultural Statistics at a glance 2010). It is, therefore, the need of hour to improve water use efficiency for wheat production. Keeping this fact in view, the present investigation was undertaken with an objective to study the effect of seed priming and pre germinated seeds in crop establishment under sub optimal soil moisture conditions in Indo-Gangetic plains, so that pre-sowing irrigation requirement of wheat crop and time period (from pre sowing irrigation to field preparation) may be reduced.

\section{MATERIALS AND METHODS}

Wheat genotype DBW 17 was used for this study and seed was obtained from Seed Project, Directorate of Wheat Research, Karnal, India. The present study was conducted at the research farm of Directorate of Wheat Research, Karnal, Haryana, India. The region is characterized by sub tropical and semi arid climate with a hot dry summer (March-June), wet monsoon season (late June - mid September) and a cool dry winter (November-February). Average annual rainfall of Karnal location is 744 $\mathrm{mm}$ of which about 80 percent is received during the monsoon. The climate is subtropical with mean maximum temperature ranging in between $34-39^{\circ} \mathrm{C}$ in summer and mean minimum temperature ranging in between $6-7^{\circ} \mathrm{C}$ in winter. The crop season received $129.7 \mathrm{~mm}$ and $36.3 \mathrm{~mm}$ rainfall during 2010-11 and 2011-12, respectively. The soil of experimental field was sandy clay loam with pH 7.3 (1:2.5 soils to water). The soil had organic carbon $0.4 \%$, available N $190 \mathrm{~kg} \mathrm{ha}^{-1}$, available P $17.8 \mathrm{~kg} \mathrm{ha}^{-1}$ and available $\mathrm{K} 165 \mathrm{~kg} \mathrm{ha}^{-1}$ at the beginning of the experiment. A field experiment comprising three main plot treatments viz. 1- seeding at optimum moisture level (17.5\%), 2- seeding at sub optimal moisture (10.9\%) and 3- seeding in dry soil followed by irrigation (4.2\%); and three sub plot treatments viz., 1- no seed priming, 2- seed priming with plain water and 3- pre germinated seed was conducted in split plot design with three replications during Rabi (winter) seasons of 2010-11 and 201112. To impose the moisture stress treatments pre sowing irrigations were given in treatment optimum moisture level, sub optimal moisture level was obtained by using the residual soil moisture after rice harvesting (no pre sowing irrigation), whereas treatment dry soil followed by irrigation was achieved three times plowing the field to air dry the field (without pre sowing irrigation). Seed priming treatment, seeds 
were soaked in normal water for about 8 hours before sowing and for pre-germinated seeds treatment; seeds were soaked in normal water over night, spread on a gunny bag and covered by another wet gunny bag for next 12 hours. The sowing of seeds were done on 18 and 6 November in 2010 and 2011, respectively and harvested on 28 April \& 1 May in 2011 and 2012, respectively. The row spacing was kept $20 \mathrm{~cm}$. Recommended doses of fertilizer $\left(150: 60: 40 \mathrm{~kg}\right.$ of $\mathrm{N}, \mathrm{P}_{2} \mathrm{O}_{5}$ and $\mathrm{K}_{2} \mathrm{O} \mathrm{ha}^{-1}$ ) were applied as part of nutrient management. Full doses of $P$ and $K$ and $1 / 3$ dose of $N$ through NPK mixture (12:32:16) and urea were applied at sowing and remaining $\mathrm{N}$ was applied equally in two splits at first ( 25 days after sowing) and second (45 days after sowing) irrigations. Soon after seed sowing one light irrigation was imposed in treatment dry sowing followed by irrigation. Subsequent irrigations were given at critical growth stages of wheat crop. For weed control one spray of Sulfosulfuron (Leader 75 WG) @ $25 \mathrm{~g} \mathrm{ha}^{-1}$ were done 10 days after first irrigation. Subsequently one hand weeding was done to keep the experimental area free from weeds. Other management practices were adopted as per recommendations of the crop under irrigated conditions. Germination count per meter square was recorded at $4^{\text {th }}$ day after sowing. Number of productive tillers per square meter from the centre of plot was measured in each plot at maturity. Plant height data were recorded by measuring the height of ten representative plants from each plot randomly. A random sample of ten spikes was taken from each plot to determine spike length at maturity. A net plot of size $6 \mathrm{~m}^{2}$ was harvested manually to obtain biomass and yield data. Thousand grains were randomly selected from each sub plot and weighed.

Water productivity and economic analysis combines physical accounting of water with yield or economic output to assess how much value is being obtained from the use of water (Abdullaev et al., 2007). For this analysis, physical water productivity was calculated by the following equation:

$$
\text { WP = Output/Q }
$$

Where,

WP is the productivity of water in $\mathrm{kg} \mathrm{m}^{-3}$, output is the productivity of wheat in $\mathrm{kg} \mathrm{ha}^{-1}$ and $\mathrm{Q}$ is water used by the crop in $\mathrm{m}^{-3} \mathrm{ha}^{-1}$.

Total amount of water used by wheat was calculated by multiplying the discharge from the tube well with total time taken for irrigating the crop throughout the season (total irrigating hours multiplied by volume of water drawn out per hour). Based on this, the average discharge of tubewell with $10 \mathrm{HP}$ was estimated at $600 \mathrm{~m}^{-3}$ ha $^{-1}$ per irrigation (Kaur et al., 2012).

For statistical analysis SAS version 10.3 had been used to analyze the observations and differences among means were further grouped into significant classes by Duncan’s New Multiple Range Test at five percent probability. 


\section{RESULTS AND DISCUSSION}

\section{Germination Indices}

Pre-germinated seeds and seed priming with normal water gave beneficial effect for seed germination, seedling emergence and subsequently crop establishment. Pre-germinated seeds and seed priming in this study resulted significantly higher germination 153 \& 167 per square meter which were significantly higher over dry seeds (136). In moisture regime treatments maximum germination was recorded for the treatment dry sowing followed by irrigation (205 per square meter) which was significantly superior to optimum and sub optimal soil moisture treatments. It seems that primed seeds decreased the time of emergence by about 50 per cent. Priming of seeds with normal water makes them rapidly imbibe water and revive metabolism and germination. This then results in higher germination rate, improved stand establishment, increased stress tolerance and ultimately higher yield. The importance of early germination, seedling emergence and rapid stand establishment and growth is quite essential to compete for water, light and nutrients.

\section{Yield Attributes}

Yield attributes viz. number of effective $/ \mathrm{m}^{2}$ (500), ear head length (10.8) and 1000 grain weight (39.08 g) were the highest in pre-germinated seeds followed by hydro primed seeds and found significantly higher than unprimed seeds. The highest yield attributes in pre-germinated seeds may be ascribed to higher number of effective tillers which lead to higher dry matter accumulation (biomass), translocation and conversion of photosynthesis in to reproductive parts. Seeds can be soaked before sowing to meet the initial seed imbibitions requirement. These results indicate that seed priming and pre-germinated seeds caused early and vigorous germination, which led into proper crop establishment under sub optimal soil moisture conditions, there by, producing higher yield attributes. Similar beneficial effects of seed priming were reported by Rajpar et al. (2006) and revealed that seedlings were significantly faster in emergence, took fewer days to mature and gave significantly higher grain yield. Among seeding methods (seeding at optimum moisture level, sub optimal moisture and in dry soil followed by irrigation) except number of effective tillers, all yield attributing characters were found non-significant. Highest number of effective tillers $/ \mathrm{m}^{2}$ (499) were recorded for the treatment seeding in dry soil followed by irrigation which was statistically superior over seeding at optimum moisture level (491) and seeding at sub optimal moisture (457).

\section{Yield}

The grain (5.49 $\left.\mathrm{t} \mathrm{ha}^{-1}\right)$ and biomass $\left(12.7 \mathrm{t} \mathrm{ha}^{-1}\right)$ yields of wheat varied significantly due to pre-germinated seeds. These were the highest under pregerminated seeds sown with optimal soil moisture and sub optimal soil moisture conditions and were significantly higher than unprimed seeds. Pre-germinated seeds 
and hydro primed seeds registered 9.2 and $5.2 \%$ higher grain yield compared to unprimed seeds, respectively. Increase in grain yield of wheat under pre-germinated seeds and seed priming treatments could be attributed to higher yield attributes whereas, the increase in biological yield was due to higher plant density and plant height. Higher grain and biomass yield in pre-germinated seeds could also be attributed to early germination and vigorous growth, consequently good crop establishment. Higher grain yield with seed priming of wheat has been also reported by Harris et al. (2001b) and Rashid et al. (2002). Harris et al. (1999) reported that early emergence and maturity in seed priming treatment could be due to advancement in metabolic state. Musa et al. (1999) also concluded that priming improve plant stand and provide benefits in term of maturity. This view was further supported by Rashid et al. (2002).

\section{Water productivity}

The highest yield was observed in $\mathrm{M}_{1} \mathrm{~S}_{3}\left(6.39 \mathrm{t} \mathrm{ha}^{-1}\right)$ during 2010-11 and $\mathrm{M}_{3} \mathrm{~S}_{3}$ (4.95 $\left.\mathrm{t} \mathrm{ha}^{-1}\right)$ during 2011-12. The information in table 4 indicates the total irrigation water (tube well water + rainfall) applied for crop under different treatments. During both the years of study, water productivity per hectare was highest in the case of pregerminated seeds technique coupled with seeding at sub optimal soil moisture level $\left(\mathrm{M}_{2} \mathrm{~S}_{3}\right)$. Productivity was higher in 2011-12 in spite of low rainfall in comparison to 2010-11 and it could be due to early sowing as compared to the year 2010-11.

Cost of irrigating per hectare of wheat was more in 2011-12 owing to marginal increase in the wages of labourers (Table 5). The quantum of water used for irrigation was low in the case of seeding at sub optimal soil moisture level under seed priming techniques. The cost of irrigation ranged from as high as INR $2232 \mathrm{ha}^{-1}$ to as low as INR 1860/ha due to sacrificing irrigation at the rate of $600 \mathrm{~m} \mathrm{ha}^{-3}$ for seeding at sub optimal soil moisture level under different seed priming techniques.

On the basis of these two years study, it can be revealed that pre-germinated and hydro primed seed sowing may be adopted to enhance seed germination, emergence, and higher biomass as well as grain yield of wheat in Indo-Gangetic plains of India. In addition this technology helps advancing the wheat sowing by about 10-15 days for avoiding the pre sowing irrigation time period require from pre sowing irrigation to field preparation. 10-15 days time period is very crucial in ricewheat cropping system, the largest cropping system of South Asia. In this region wheat planting usually gets delayed in Rice-Wheat system due to late harvesting of rice which can cause wheat yield penalty. Secondly poor establishment of crop due to lack of optimum soil moisture could be a major constraint for proper crop establishment in other crop sequences. Integrating pre-germinated seeds, seed priming with surface seeding can be a cost effective strategies for enhancing productivity in these rice fallows. On the other hand, good establishment increases

competitiveness against weeds, increases tolerance to dry spells maximizes yields and save the time and cost of one irrigation which can also advance the sowing of 
wheat after rice crop. Clark et al., 2001 also expressed their views in the same manner. The benefits accrued for the country due to saving irrigation water was estimated in view of the overall deteriorating water situation. The average productivity of wheat was $4.56 \mathrm{t} \mathrm{ha}^{-1}$ in 2010-11 and 5.85 t ha ${ }^{-1}$ in 2011-12 (Table 4). Production was estimated at 45.58 MT in 2010-11 and 58.47 MT in 2011-12 and the value of production stood at INR 533247 million and INR 751340 million respectively for 2010-11 and 2011-12. Following the water conservation technique, about 20 percent of irrigation water @ $600 \mathrm{~m} \mathrm{ha}^{-3}$ and 20 percent of energy @ 24 units ha ${ }^{-1}$ could be saved for the country as a whole under rice-wheat system.

\section{CONCLUSION}

Pre-germinated seeds and seed priming is helpful in reducing the risk of poor stand establishment under sub optimal soil moisture conditions. Pre-germinated seeds and hydro priming of seeds are the simple, cost effective and useful technique, which can advance the wheat sowing by about 10 days and beneficial for both crop thereby increasing wheat yield.

\section{REFERENCES}

Abdullaev, I., Husan, M.U., \& Jumaboev, K. 2007. Water is saving and economic impacts of land leveling: The case study of cotton production in Tajikistan, Irrigation Drainage System, 21, 251-263

Agricultural Satistics At a glance .2010. Directorate of Economics and Statistics. Department of Agriculture and Cooperation. Ministry of Agriculture, Govt. of India

Brocklehurst, P.A., \& Dearman, J. 2008. Interaction between seed priming treatments and nine seed lots of carrot, celery and onion II. Seedling emergence and plant growth, Annals of Applied Biology, 102, 583-593

Clark, L.J., Whalley, W.R., Ellis-Jones, J., Dent, K., Rowse, H.R., Finch-Savage, W.E., Gatsai, T., Jasi, L., Kaseke, N.E., Murungu, F.S., Riches, C.R. \& Chiduza, C. 2001. On farm seed priming in maize: A physiological evaluation, Eastern and Southern Africa Regional Maize Conference. pp. 268-273

Farooq, M.,. Basra S.M.A., Khalid, M., Tabassum R., \& Mehmood T. 2006. Nutrient homeostasis, metabolism of reserves and seedling vigor as affected by seed priming in coarse rice, Canadian Journal of Botany, 84 :1196-1202

Farooq, M., Wahid A., Kobayashi N., Fujita D., \& S. Basra M.A. 2009a. Plant drought stress: effects, mechanisms and management, Agronomy for Sustainable Development, 29: 185-212

Farooq, M., Basra S. M. A, Wahid A., Khaliq A., \& Kobayashi N. 2009b. Rice seed invigoration: a review. In: E. Lich Lichtfouse, ed. Organic Farming, Pest Control and Remediation of Soil Pollutants, pp. 137-175. Springer, the Netherlands

Food and Agriculture Organization. 2012. Press Release on World water day 22 March 2012

Harris, D. 1996. The effects of manure, genotype, seed priming, depth and date of sowing on the emergence and early growth of sorghum bicolor (L.) Moench in semi arid Botswana, Soil and Tillage Research, 40: 73-88 
Harris, D., \& Hollington, P.A. 2001. 'On-farm' seed priming - an update. Tropical Agriculture Association (UK) Newsletter, 21(4):7

Harris, D., Joshi, A., Khan, P.A., Gothkar, P., \& Sodhi, S. 1999. On farm seed priming in semi-arid agriculture: development and evaluation in maize, rice and chickpea in India using participatory methods, Experimental Agriculture, 35: 15-29

Harris, D., Pathan, A.K., Gothkar, P., Joshi, A., Chiwasa, W., \& Nyamudeza, P. 2001b. Onfarm seed priming: use participatory methods to revive and refine a key technology, Agricultural System, 69 (1-2): 151-164

IPCC, 2007: Climate Change .2007. The Physical Science Basis. Contribution of Working Group I to the Fourth Assessment Report of the Intergovernmental Panel on Climate Change [Solomon, S., D. Qin, M. Manning, Z. Chen, M. Marquis, K.B. Averyt, M.Tignor and H.L. Miller (eds.)]. Cambridge University Press, Cambridge, United Kingdom and New York, NY, USA

Jafar, M. Z., Farooq, M., Cheema, M. A., Afzal, I., Basra, S. M. A., Wahid, M. A., Aziz, T., \& Shahid, M. 2012. Improving the performance of wheat by seed priming under saline conditions. Journal of Agronomy and Crop Science, 198: 38-45

Johanson, C., Musa, A.M., Kumar Rao, J.V.D.K., Harris, D., Ali, M.Y., \& Lauren, J.G. 2004. Molybdenum response of chickpea in the High Barind Track of Bangladesh and in Eastern India. In International workshop on Agricultural strategies to reduce micronutrient problems in mountains and other marginal areas in South and South East Asia. Kathmandu, 8-10 September 2004. Nepal Agricultural Research Council

Kaya, M. D., Okçu, G., Atak, M., ÇIkIlI, Y., \& KolsarIcI, O. 2006. Seed treatments to overcome salt and drought stress during germination in sunflower (Helianthus annuus L.). European Journal of Agronomy, 24: 291-295

Kaur, B., Singh, S., Garg, B.R., Singh, J.M., \& Singh, J. 2012. Enhancing water productivity through on-farm resource conservation technology in Punjab agriculture. Agricultural Economics Research Review, 25(1): 79-85

Musa, A.M., Johansen C., Kumar J. \& Harris D. 1999. Response of chickpea to seed priming in the High Barind Tract of Bangladesh. International Chickpea and Pigeonpea Newsletter, 6: 20-22

Rajpar, I., Khanif Y.M. \& Memon A.A. 2006. Effect of Seed Priming on Growth and Yield of Wheat (Triticum aestivum L.) Under Non-Saline Conditions. International Journal of Agricultural Research, 1 (3): 259-264

Rashid, A., Harris, D., Hollington, P.A. \& Khattak, R.A. 2002. On farm seed priming: a key technology for improving the livelihoods of resource poor-farmers on saline lands. Pp. 423-431 in: R. Ahmad and K.A. Malik (eds.) 'Prospects for Saline Agriculture'. Kluwer Academic Publishers. The Netherlands

Sharma, I., Chatrath, R., and Sendhil, R. 2013. Climate change and sustainable food security SP 4-2013. Research, Policy and Institutional Dynamics in Enhancing Wheat production and productivity in India. PK Shetty, S. Ayyappan and MS Swaminathan (eds.) 
Table 1: Effect of seed priming and seeding method on yield attributing characters of wheat under sub-optimal soil moisture conditions

\begin{tabular}{|c|c|c|c|c|c|c|c|c|c|c|c|c|c|c|c|}
\hline \multirow{2}{*}{ Treatments } & \multicolumn{3}{|c|}{ Germination $/ \mathbf{m}^{2}$} & \multicolumn{3}{|c|}{ Productive tillers $/ \mathbf{m}^{2}$} & \multicolumn{3}{|c|}{ Spike length (cm) } & \multicolumn{3}{|c|}{ Plant height (cm) } & \multicolumn{3}{|c|}{1000 grain weight (g) } \\
\hline & \begin{tabular}{|l|}
$2010-11$ \\
\end{tabular} & 2011-12 & Pooled & 2010-11 & 2011-12 & Pooled & 2010-11 & 2011-12 & Pooled & 2010-11 & 2011-12 & Pooled & 2010-11 & 2011-12 & Pooled \\
\hline \multicolumn{16}{|c|}{ A. Seeding Method } \\
\hline M1* & 140 & 142 & 141 & 444 & 539 & 491 & 10.2 & 10.3 & 10.2 & 83.4 & 90.8 & 87.8 & 36.7 & 41.0 & 38.9 \\
\hline M3 & 204 & 205 & 205 & 440 & 568 & 504 & 9.5 & 9.5 & 9.5 & 84.2 & 92.1 & 88.0 & 37.2 & 40.3 & 38.8 \\
\hline SEm \pm & 6.0 & 5.0 & 5.4 & 4.6 & 12.1 & 7.3 & 0.23 & 0.22 & 0.224 & 0.72 & 0.83 & 0.92 & 0.36 & 0.24 & 0.18 \\
\hline $\mathrm{CD}(\mathrm{P}=0.05)$ & 23.4 & 19.7 & 21.1 & 18.2 & 47.9 & 28.5 & 0.90 & 0.8 & NS & 2.8 & 2.3 & NS & 1.4 & 0.9 & NS \\
\hline \multicolumn{16}{|c|}{ B. Seed Priming } \\
\hline S3 & 165 & 169 & 167 & 432 & 579 & 500 & 10.3 & 10.2 & 10.2 & 83.9 & 92.2 & 87.9 & 37.1 & 41.1 & 39.1 \\
\hline SEm \pm & 5.2 & 7.7 & 6.4 & 4.2 & 10.5 & 6.1 & 0.16 & 0.17 & 0.175 & 0.48 & 0.62 & 0.17 & 0.16 & 0.25 & 0.13 \\
\hline $\mathrm{CD}(\mathrm{P}=0.05)$ & 16.2 & 23.8 & 19.7 & 12.9 & 32.3 & 19.1 & 0.51 & 0.55 & NS & 1.4 & 1.4 & NS & 0.5 & 0.7 & 0.4 \\
\hline
\end{tabular}

Table 2: Effect of seed priming and seeding method on yield of wheat under sub-optimal soil moisture conditions

\begin{tabular}{|c|c|c|c|c|c|c|}
\hline Treatments & \multicolumn{3}{|c|}{ Grain Yield (t ha $\left.{ }^{-1}\right)$} & \multicolumn{3}{|c|}{ Biomass Yield $\left(\mathrm{t} \mathrm{ha}^{-1}\right)$} \\
\hline M1* & 4.67 & 5.89 & 5.28 & 10.63 & 14.29 & 12.49 \\
\hline M2 & 4.56 & 5.85 & 5.20 & 10.54 & 14.21 & 12.45 \\
\hline SEm \pm & 0.053 & 0.048 & 0.043 & 0.049 & 0.081 & 0.019 \\
\hline $\mathrm{CD}(\mathrm{P}=0.05)$ & NS & NS & NS & NS & 0.315 & 0.076 \\
\hline \multicolumn{7}{|l|}{ B. Seed Priming } \\
\hline SEm \pm & 0.076 & 0.071 & 0.057 & 0.083 & 0.089 & 0.072 \\
\hline $\mathrm{CD}(\mathrm{P}=0.05)$ & 0.235 & 0.219 & 0.175 & NS & 0.273 & 0.221 \\
\hline
\end{tabular}

* M1: Seeding at optimum moisture Level, M2: Seeding at sub optimal soil moisture level

M3: Seeding in dry soil followed by irrigation

$\mathrm{S}_{1}$ : No seed priming, S2: Seed priming, S3: Sprouted seed 
Table 3: Interaction effects of seed priming and seeding method on crop establishment, growth and yield of wheat during the year 2011-11 and 2011-12 (Pooled analysis)

\begin{tabular}{|c|c|c|c|c|c|c|}
\hline Treatments & $\begin{array}{c}\text { No. of } \\
\text { Tillers } \mathbf{~ m}^{2}\end{array}$ & $\begin{array}{c}\text { Earhead } \\
\text { Length }(\mathrm{cm})\end{array}$ & $\begin{array}{c}\text { Plant } \\
\text { Height }(\mathrm{cm})\end{array}$ & $\begin{array}{c}\text { Biomass } \\
\left(\mathrm{t} \mathrm{ha}^{-1}\right)\end{array}$ & $\begin{array}{l}\text { Grain } \\
\text { Yield (t } \\
\left.\text { ha }^{-1}\right)\end{array}$ & $\begin{array}{l}1000 \text { grain } \\
\text { weight (g) }\end{array}$ \\
\hline $\mathrm{M}_{1} \mathrm{~S}_{1}$ & 469.68 & 9.90 & 87.57 & 12.25 & 4.98 & 38.68 \\
\hline $\mathrm{M}_{1} \mathrm{~S}_{2}$ & 485.11 & 10.25 & 88.77 & 12.66 & 5.25 & 38.17 \\
\hline $\mathrm{M}_{1} \mathrm{~S}_{3}$ & 520.41 & 10.57 & 86.94 & 12.56 & 5.61 & 39.78 \\
\hline $\mathrm{M}_{2} \mathrm{~S}_{1}$ & 424.72 & 9.71 & 88.52 & 12.53 & 5.09 & 38.36 \\
\hline $\mathrm{M}_{2} \mathrm{~S}_{2}$ & 449.99 & 10.73 & 88.09 & 12.17 & 5.16 & 38.65 \\
\hline $\mathrm{M}_{2} \mathrm{~S}_{3}$ & 496.10 & 10.01 & 88.50 & 12.55 & 5.37 & 38.24 \\
\hline $\mathrm{M}_{3} \mathrm{~S}_{1}$ & 500.55 & 9.22 & 87.44 & 12.33 & 5.01 & 37.92 \\
\hline $\mathrm{M}_{3} \mathrm{~S}_{2}$ & 512.35 & 9.43 & 88.17 & 12.91 & 5.51 & 39.18 \\
\hline $\mathrm{M}_{3} \mathrm{~S}_{3}$ & 485.68 & 9.95 & 88.42 & 13.12 & 5.49 & 39.22 \\
\hline $\operatorname{SEm} \pm$ & 10.73 & 0.30 & 0.59 & 0.12 & 0.09 & 0.23 \\
\hline $\mathrm{CD}(\mathrm{P}=0.05)$ & 33.06 & NS & 0.95 & 0.38 & NS & 0.72 \\
\hline
\end{tabular}

* M1: Seeding at optimum moisture Level, M2: Seeding at sub optimal soil moisture level

M3: Seeding in dry soil followed by irrigation

$\mathrm{S}_{1}$ : No seed priming, S2: Seed priming, S3: Sprouted seed

Table 4: Effect of sprouted seeds and seed priming on water productivity of wheat crop

\begin{tabular}{l|c|c|c|c|c|c}
\hline Treatment & \multicolumn{3}{|c|}{$\begin{array}{c}\text { Total irrigation water* } \\
\text { application }\left(\mathbf{m ~ h a}^{-3} \text { ) }\right.\end{array}$} & \multicolumn{3}{c}{$\begin{array}{c}\text { Water productivity per ha } \\
\text { (kg grain/m }\end{array}$} \\
& $\mathbf{2 0 1 0 - 1 1}$ & $\mathbf{2 0 1 1 - 1 2}$ & Pooled & $\mathbf{2 0 1 0 - 1 1}$ & $\mathbf{2 0 1 1 - 1 2}$ & Pooled \\
\hline $\mathrm{M}_{1} \mathrm{~S}_{1}$ & 3642 & 3612 & 3627 & 1.22 & 1.52 & 1.37 \\
$\mathrm{M}_{1} \mathrm{~S}_{2}$ & 3642 & 3612 & 3627 & 1.30 & 1.60 & 1.45 \\
$\mathrm{M}_{1} \mathrm{~S}_{3}$ & 3642 & 3612 & 3627 & 1.32 & 1.77 & 1.55 \\
$\mathrm{M}_{2} \mathrm{~S}_{1}$ & 3042 & 3012 & 3027 & 1.47 & 1.89 & 1.68 \\
$\mathrm{M}_{2} \mathrm{~S}_{2}$ & 3042 & 3012 & 3027 & 1.50 & 1.91 & 1.70 \\
$\mathrm{M}_{2} \mathrm{~S}_{3}$ & 3042 & 3012 & 3027 & 1.52 & 2.02 & 1.77 \\
$\mathrm{M}_{3} \mathrm{~S}_{1}$ & 3642 & 3612 & 3627 & 1.21 & 1.56 & 1.38 \\
$\mathrm{M}_{3} \mathrm{~S}_{2}$ & 3642 & 3612 & 3627 & 1.27 & 1.76 & 1.52 \\
$\mathrm{M}_{3} \mathrm{~S}_{3}$ & 3642 & 3612 & 3627 & 1.36 & 1.67 & 1.51 \\
\hline
\end{tabular}

Note: $*$ Calculated on the basis of irrigation water @ $600 \mathrm{~m} \mathrm{ha}^{-3}$ per irrigation + rainfall during the crop season, 2010-11 $=129.7 \mathrm{~mm}$, and 2011-12 $=36.3 \mathrm{~mm}$. 


\section{Table 5: Cost of irrigation influenced by seeding of hydro-primed and pre-} germinated wheat seeds

\begin{tabular}{|c|c|c|c|c|c|c|}
\hline \multirow{3}{*}{ Treatment } & \multicolumn{6}{|c|}{ Irrigation water } \\
\hline & \multicolumn{2}{|c|}{ 2010-11 } & \multicolumn{2}{|c|}{ 2011-12 } & \multicolumn{2}{|c|}{ Pooled } \\
\hline & $\begin{array}{c}\text { Quantity (m } \\
\text { ha }^{-3} \text { ) }\end{array}$ & $\begin{array}{c}\text { Cost } \\
\left(\text { INR ha }^{-1}\right)\end{array}$ & \begin{tabular}{|c|} 
Quantity (m \\
ha $^{-3}$ )
\end{tabular} & $\begin{array}{c}\text { Cost } \\
\left(\text { INR ha }^{-1}\right)\end{array}$ & $\begin{array}{c}\text { Quantity (m } \\
\text { ha }^{-3} \text { ) }\end{array}$ & $\begin{array}{c}\text { Cost } \\
\left(\text { INR ha }^{-1}\right)\end{array}$ \\
\hline $\mathrm{M}_{1} \mathrm{~S}_{1}$ & 3600 & 2172 & 3600 & 2292 & 3600 & 2232 \\
\hline $\mathrm{M}_{1} \mathrm{~S}_{2}$ & 3600 & 2172 & 3600 & 2292 & 3600 & 2232 \\
\hline $\mathrm{M}_{1} \mathrm{~S}_{3}$ & 3600 & 2172 & 3600 & 2292 & 3600 & 2232 \\
\hline $\mathrm{M}_{2} \mathrm{~S}_{1}$ & 3000 & 1810 & 3000 & 1910 & 3000 & 1860 \\
\hline $\mathrm{M}_{2} \mathrm{~S}_{2}$ & 3000 & 1810 & 3000 & 1910 & 3000 & 1860 \\
\hline $\mathrm{M}_{2} \mathrm{~S}_{3}$ & 3000 & 1810 & 3000 & 1910 & 3000 & 1860 \\
\hline $\mathrm{M}_{3} \mathrm{~S}_{1}$ & 3600 & 2172 & 3600 & 2292 & 3600 & 2232 \\
\hline $\mathrm{M}_{3} \mathrm{~S}_{2}$ & 3600 & 2172 & 3600 & 2292 & 3600 & 2232 \\
\hline $\mathrm{M}_{3} \mathrm{~S}_{3}$ & 3600 & 2172 & 3600 & 2292 & 3600 & 2232 \\
\hline Mean & 3400 & 2051 & 3400 & 2164 & 3400 & 2108 \\
\hline
\end{tabular}

* M1: Seeding at optimum moisture Level, M2: Seeding at sub optimal soil moisture level, M3: Seeding in dry soil followed by irrigation, $\mathrm{S}_{1}$ : No seed priming, S2: Seed priming, S3: Sprouted seed

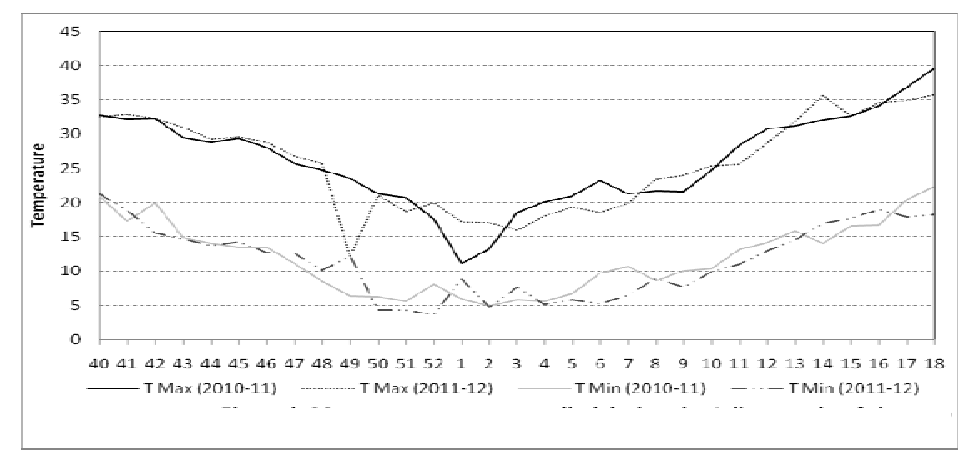

Figure 1: Weather data for the Rabi season of 2010-11 \& 2011-12

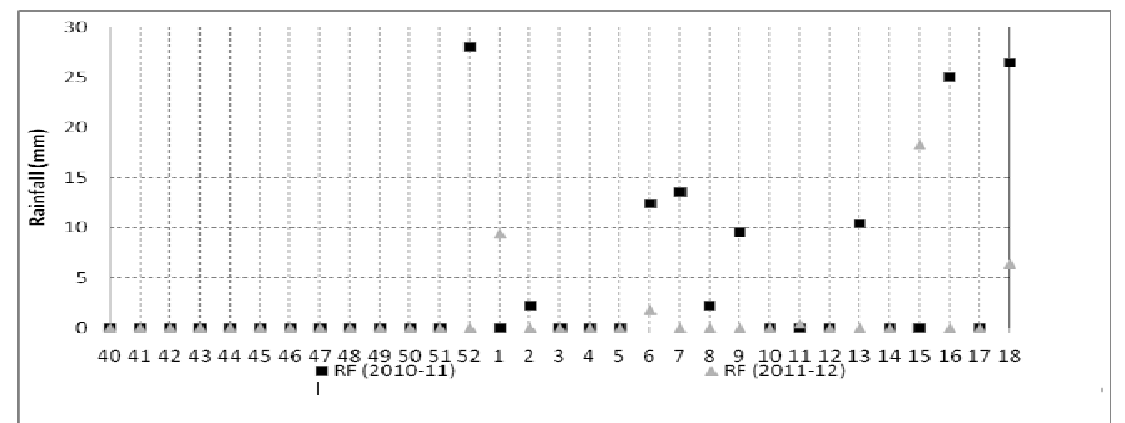

Figure 2: Mean rainfall prevailed during the Julian weeks of the crop season 